UDC $66.061 .351+546.791 .6+661.879 .1$

\title{
PHYSICAL AND CHEMICAL FOUNDATIONS OF THE EXTRACTION REFINING OF NATURAL URANIUM
}

\author{
A.P. Mukhachev ${ }^{1}$, D.O. Yelatontsev ${ }^{2}$, O.A. Kharitonova ${ }^{2}$ \\ ${ }^{1}$ Institute of Geotechnical Mechanics named by N. Poljakov, Dnipro, Ukraine; \\ ${ }^{2}$ Dnipro State Technical University, Kamianske, Ukraine \\ E-mail:map45@ukr.net
}

The paper presents the results of studies of the physicochemical processes of the extraction and nitric acid purification of uranium salts obtained by the method of precipitation of ammonium uranyl carbonate (AUC) from ore solutions of leaching of uranium and polymetallic ores with their subsequent dissolution in nitric acid. It is shown that the process of extraction on a mixture of tributyl phosphate (TBP) in kerosene makes it possible to obtain high-purity uranium oxide. For the selective extraction of impurities, the process of uranium extraction from the nitric acid medium was carried out with a mixture of TBP and di(2-ethylhexyl) phosphoric acid (DEHPA) in kerosene. The first uranium concentration $40 \ldots 50 \mathrm{~g} / \mathrm{L}$ simulated the process of uranium desorption, the second $\leq 100 \mathrm{~g} / \mathrm{L}$ simulated the process of dissolution of uranium oxide. The study of the uranium extraction made it possible to determine the required number of extraction stages to achieve the minimum uranium content in the raffinate and the maximum extractant capacity, which ensured the specified coefficients of uranium purification from metal impurities ( $\mathrm{V}$, Mo, etc.). After extraction, the nitric acid raffinate served as a raw material for the production of a mineral fertilizer - sodium nitrate.

\section{INTRODUCTION}

For the first time, the uranium extraction process (PUREX-process) was used in the reprocessing of spent nuclear fuel to obtain plutonium [1]. The history of the use of extraction processes in natural uranium production technology is described in [2]. The most widely used uranium extraction was in sulfuric acid and phosphoric acid schemes with the use of extractants TBP, DEHPA, trialkylamine (TAA), and some others [3].

Uranium oxide concentrate as the end product of uranium ore processing was obtained by the roasting of AUC crystals precipitated by ammonium carbonate from ore solutions. The resulting concentrate contained no more than $60 \%$ uranium and required additional purification. The introduction of the process of sorption of uranium on ion-exchange resins made it possible to selectively extract uranium from the ore solution and increase its concentration after desorption to $20 \ldots 30 \mathrm{~g} / \mathrm{L}$. Obtaining "yellow cake" concentrate after in-situ leaching (ISL) made it possible to increase the concentration of uranium to $80 \ldots 100 \mathrm{~g} / \mathrm{L}$. Both solutions had to be processed by extraction to obtain purified uranium oxide, which is necessary to obtain nuclear grade uranium hexafluoride $\mathrm{UF}_{6}$.

The process of leaching uranium ores from pulps is usually based on the use of sulfuric acid, which, after sorption, was neutralized with milk of lime to $\mathrm{pH}=7$, and gypsum is sent to a special storage facility. The use of nitric acid instead of sulfuric acid made it possible to increase the degree of uranium extraction from 90 to $99 \%$, while its neutralization with soda made it possible to obtain sodium nitrate, as well as "nitrofoska"- a complex fertilizer with nutrient content of $40 \%$. The process of extracting uranium from nitric acid media has not been studied or used yet.

Concentrate of natural uranium in the form of uranium oxide is a standard intermediate product during uranium ore processing. The requirements for the quality of uranium oxide are regulated by the international standard ASTM-C-967, which determines the uranium content in the concentrate not less than $84 \%$, and impurities - not more than $1 \cdot 10^{-2} \%$.

Before the introduction of the extraction process on an industrial scale, the purification of uranium from impurities was based on the laborious processes of crystallization and recrystallization of AUC. Metallic impurities that passed into uranium oxide after roasting were removed due to different solubility during the precipitation of $\mathrm{UF}_{4} \cdot \mathrm{nH}_{2} \mathrm{O}$. The advent of the TBP extractant made it possible to use it for deeper purification of uranyl nitrate.

The sorption of uranium on the SG-1 cation exchanger was the first known in the uranium industry. It allowed concentrating uranium up to 150 times and was first introduced at the GP "VostGOK" (Zhovti Vody) in 1961.

Because ore solutions contained up to $1 \mathrm{~g} / \mathrm{L}$ of uranium, the extraction process was impossible due to the large volume of low-concentration solutions. The use of concentrates with $60 \%$ of uranium made it possible to obtain a solution with a uranium concentration of up to $100 \mathrm{~g} / \mathrm{L}$, suitable for studying the extraction process to solve the following problems:

1. Develop an extraction scheme for the purification of uranium from solutions with 50 and $100 \mathrm{~g} / \mathrm{L}$ of uranium.

2. Optimize the technological parameters of the extraction and re-extraction of uranium to achieve the required quality of uranium oxide.

3. Develop the process of solid-phase uranium regeneration by an ammonium carbonate solution.

The purpose of this work wasto study the conditions for the extraction of uranium with a mixture of TBP and kerosene in a nitric acid medium, as well as to investigate the peculiarities of solid-phase re-extraction of uranium by ammonium carbonate. 


\section{MATERIALS AND METHODS}

The end product of uranium production technology fromoreis chemical concentrates, which must bepurified according to the scheme of double salting out of AUC. To remove impurities, it is necessary to carry out extraction from nitric acid solutions obtained from dissolving various chemical concentrates in nitric acid at excess acidity of $50 \mathrm{~g} / \mathrm{L}$ in our trials, the solid phase was separated by filtration, and the nitric acid filtrate served as a starting solution for studying the extraction process. In this case, two samples were taken: the first was based on the content of $50 \mathrm{~g} / \mathrm{L}$ of uranium, the second was prepared by dissolving a mixture of a chemical concentrate in $48 \% \mathrm{HNO}_{3}$.

Chemical concentrate of uranium in the form of crystals with a uranium content of $40 \ldots 60 \%$ was dissolved in $48 \%$ nitric acid at an excess acidity of $50 \mathrm{~g} / \mathrm{L}$ to obtain 2 solutions:

- first, with a uranium content of $50 \mathrm{~g} / \mathrm{L}$;

- second, with a uranium content of $100 \mathrm{~g} / \mathrm{L}$.

Both products were analyzed for the content of $\mathrm{U}, \mathrm{K}$, $\mathrm{Na}, \mathrm{Al}, \mathrm{S}, \mathrm{P}, \mathrm{Fe}, \mathrm{Cu}, \mathrm{Mg}, \mathrm{Mn}, \mathrm{Si}$, after which their specific weight was measured.

After the separation of the solid phase, the filtrate served as a starting solution for studying the extraction process. TBP with a specific gravity of $0.96 \mathrm{~g} / \mathrm{mL}$ was used as an extractant. Kerosene with a specific gravity of $0.817 \mathrm{~g} / \mathrm{mL}$ was used as an inert diluent. One volume of TBP was mixed with three volumes of kerosene, so TBP concentration in the mixture was 28 wt.\%. A mixture with a specific gravity of $0.8 \mathrm{~g} / \mathrm{mL}$ was treated with a $0.5 \%$ solution of nitric acid at a ratio of $1: 2$. During the extraction, the number of stages and the distribution coefficient of uranium over the stages were determined at a ratio of 1:2. The extraction was carried out in a separatory funnel for $10 \mathrm{~min}$. The aqueous phase after the first stage of extraction was sent to the second stage and so on. After each stage, the aqueous and organic phases were analyzed for uranium content, then the distribution coefficient of uranium was calculated. The extraction was terminated when the uranium content in the raffinate was less than $50 \mathrm{mg} / \mathrm{L}$.

Determining the number of extraction stages and the distribution coefficient of uranium over the stages were carried out on two nitric acid solutions with a uranium concentration of 50 and $100 \mathrm{~g} / \mathrm{L}$. To determine the number of extraction stages and the distribution coefficient of uranium over the stages, a certain amount of a nitric acid solution and an organic phase (at a phase ratio of 1:1) were taken, which were mixed by shaking in a separating funnel for $10 \mathrm{~min}$. The water phase that has passed the first extractionstage, served as the starting point for the second stage of extraction with fresh extractant and so on.

To determine the distribution coefficient of uranium over the extraction stages, the organic and aqueous phases were analyzed for the uranium content. The distribution coefficient was calculated by the equation:

$$
\alpha=C_{\text {org }} / C_{\text {aq }},
$$

where $\alpha$ is the distribution coefficient; $C_{\mathrm{org}}$ is the concentration of uranium in the organic phase; $C_{\mathrm{aq}}$ is the concentration of uranium in the equilibrium aqueous phase.

Re-extraction of uranium was carried out from the organic phase with a uranium content of $30 \mathrm{~g} / \mathrm{L}$. An ammonium carbonate solution with a concentration of $214 \mathrm{~g} / \mathrm{L}$ was used as a stripping agent. We took $50 \mathrm{~mL}$ of the organic phase and $100 \mathrm{~mL}$ of the ammonium carbonate solution. The volume ratio of the organic and aqueous phases was 1:2. Such a ratio was chosen so that after stripping, the excess carbonate content in the aqueous phase would not be lower than $150 \mathrm{~g} / \mathrm{L}$, i.e., salting out of uranium occurred simultaneously with the stripping. The contact of the ammonium carbonate solution and the organic phase was carried out in a separating funnel with shaking. In this case, the contact time varied from 5 to $60 \mathrm{~min}$. After re-extraction, AUC crystals were separated from the mother liquor by filtration and the organic phase from the mother liquor by separation after $10 \mathrm{~min}$ of settling. The organic phase was then analyzed for uranium content.

When determining the effect of excess carbonate content on the degree of re-extraction, the ratio of the organic and aqueous phases was $1: 1$, the contact time was $30 \mathrm{~min}$. The specified excess carbonate content in the carbonate mother liquor was established by the addition of dry ammonium carbonate. The separation of the AUC crystals, the carbonate mother liquor, and the organic phase was carried out in the same way as in determining the influence of the contact time on the degree of uranium re-extraction. After separation, the organic phase was analyzed for uranium content

The nitric acid solution was subjected to five-fold countercurrent extractions with a ratio of organic and aqueous phases of $2: 1$, and a contact time of $3 \mathrm{~min}$. The separation and contacting of phases were carried out in a separating funnel. After five-fold extraction, the aqueous phase was filtered and washed with kerosene (2 volumes of kerosene per 1 volume of the aqueous phase) and analyzed. Washing of the aqueous phase with kerosene was carried out to trap TBP. After the first extraction, the organic phase was removed for stripping of uranium with a saturated solution of ammonium carbonate in a separating funnel with a contact time of $30 \mathrm{~min}$ and a ratio of organic and aqueous phases of 1:1. The precipitated AUC crystals were separated from the aqueous and organic phases by filtration. The crystals were calcined in a muffle at $800{ }^{\circ} \mathrm{C}$ and analyzed.

The re-extraction of uranium from the organic phase was carried out not with a fresh solution of ammonium carbonate, but with a carbonate mother liquor obtained from the previous experiment, which was preliminarily saturated with dry ammonium carbonate. Thus, the same carbonate mother liquor was used several times as a stripping agent.

During the extraction, the conditions of maximum saturation of the extractant were determined at which the majority of impurities and no uranium remained in the raffinate. The raffinate after the second stage was neutralized with soda to get $\mathrm{NaNO}_{3}$ solution with a concentration of $200 \mathrm{~g} / \mathrm{L}$ and sent to the fertilizer production. 


\section{RESULTS AND DISCUSSION}

After analyzing the initial solutions, the content of the main impurities was determined (Table 1).

It can be seen from the above data that the main impurities that determine the consumption of nitric acid are nitrates of manganese, aluminum, iron, sodium, and magnesium.

The dissolution of the uranium chemical concentrate and impurities in nitric acid is described by equations:

$$
\begin{aligned}
& \quad \mathrm{Na}_{2} \mathrm{U}_{2} \mathrm{O}_{7}+6 \mathrm{HNO}_{3} \rightarrow \\
& \quad \rightarrow 2 \mathrm{UO}_{2}\left(\mathrm{NO}_{3}\right)_{2}+2 \mathrm{NaNO}_{3}+3 \mathrm{H}_{2} \mathrm{O}, \\
& \mathrm{MeO}+2 \mathrm{HNO}_{3} \rightarrow \mathrm{Me}\left(\mathrm{NO}_{3}\right)_{2}+\mathrm{H}_{2} \mathrm{O},
\end{aligned}
$$

where Me is bivalent metal.

A determination of the equilibrium distribution of uranium over the extraction stages (Table 2) showed that 5-6 extraction stages are sufficient for the deep extraction of uranium.
From Table 2 it follows that after five stages of extraction of the nitric acid solution, it is possible to obtain a uranium content in the aqueous phase of $50 \mathrm{mg} / \mathrm{L}$. At the same time, the distribution coefficient of uranium by stages fluctuates in the range of 2.5...4.0.

The processes of uranium extraction using TBP and its stripping with ammonium carbonate are described by equations:

$$
\begin{aligned}
& \mathrm{UO}_{2}\left(\mathrm{NO}_{3}\right)_{2}+\mathrm{TBP} \rightarrow \mathrm{TBP} \cdot \mathrm{UO}_{2}\left(\mathrm{NO}_{3}\right)_{2}, \\
& \mathrm{TBP} \cdot \mathrm{UO}_{2}\left(\mathrm{NO}_{3}\right)_{2}+3\left(\mathrm{NH}_{4}\right)_{2} \mathrm{CO}_{3} \rightarrow \\
& \rightarrow\left(\mathrm{NH}_{4}\right)_{4}\left[\mathrm{UO}_{2}\left(\mathrm{CO}_{3}\right)_{3}\right]+2 \mathrm{NH}_{4} \mathrm{NO}_{3}+\mathrm{TBP} .
\end{aligned}
$$

As shown (Table 3), the distribution coefficient of uranium remains constant when the contact time changes from one minute to twenty minutes. Consequently, the equilibrium distribution of uranium between the phases is

\begin{tabular}{|c|c|c|c|c|c|c|c|c|c|c|c|c|c|c|}
\hline \multirow[b]{2}{*}{ Name } & \multirow{2}{*}{$\begin{array}{c}\text { Acidity, } \\
\mathrm{g} / \mathrm{L}\end{array}$} & \multirow{2}{*}{$\begin{array}{c}\text { Specific } \\
\text { weight, } \\
\mathrm{g} / \mathrm{mL}\end{array}$} & \multicolumn{12}{|c|}{ Content of components, g/L } \\
\hline & & & $\mathrm{U}$ & $\mathrm{K}$ & $\mathrm{Na}$ & $\mathrm{Al}$ & S & $\mathrm{Fe}$ & $\mathrm{Ca}$ & $\mathrm{Mg}$ & Mn & $\mathrm{P}$ & $\mathrm{SiO}_{2}$ & $\mathrm{Cu}$ \\
\hline $\begin{array}{l}\text { Nitric acid } \\
\text { solution No. } 1\end{array}$ & 50.0 & 1.106 & 46 & 0.015 & 0.11 & 1.94 & 0.83 & 0.27 & 0.17 & 0.21 & 0.46 & 0.10 & 0.16 & 0.07 \\
\hline $\begin{array}{l}\text { Nitric acid } \\
\text { solution No. } 2\end{array}$ & 48.7 & 1.196 & 105 & 0.250 & 1.30 & 4.33 & 1.74 & 0.71 & 0.23 & 0.45 & 1.78 & 0.18 & 0.21 & 0.13 \\
\hline
\end{tabular}
achieved upon contact for $1 \mathrm{~min}$.

The kinetic studies and the effect of carbonate content on the degree of re-extraction are shown in Table 4.

Table 1

Chemical composition of the nitric acid solutions

Table 2

Results of uranium extraction and distribution

\begin{tabular}{|c|c|c|c|c|}
\hline \multirow{2}{*}{ Name } & $\begin{array}{c}\text { Extraction } \\
\text { stage }\end{array}$ & $\begin{array}{c}\text { Uranium content in te } \\
\text { organic phase, } \mathrm{g} / \mathrm{L}\end{array}$ & $\begin{array}{c}\text { Uranium content in the } \\
\text { aqueous phase, } \mathrm{g} / \mathrm{L}\end{array}$ & $\begin{array}{c}\text { Uranium distribution } \\
\text { coefficient }\end{array}$ \\
\cline { 2 - 5 } & 1 & 30.7 & 12.1 & 2.54 \\
\cline { 2 - 5 } & 2 & 10.8 & 3.20 & 3.38 \\
\cline { 2 - 5 } & 3 & 2.61 & 0.69 & 3.78 \\
\cline { 2 - 5 } sitric acid & 4 & 0.464 & 0.13 & 3.56 \\
\hline \multirow{4}{*}{$\begin{array}{l}\text { Nitric acid } \\
\text { solution No. } 2\end{array}$} & 5 & 0.123 & 0.047 & 2.66 \\
\cline { 2 - 5 } & 1 & 64.1 & 24.5 & 2.62 \\
\cline { 2 - 5 } & 2 & 40.0 & 14.5 & 2.76 \\
\cline { 2 - 5 } & 5 & 12.45 & 3.50 & 3.56 \\
\cline { 2 - 5 } & 6 & 2.53 & 0.61 & 3.15 \\
\hline
\end{tabular}

Table 3

Influence of contact time on the distribution coefficient of uranium

\begin{tabular}{|c|c|c|c|}
\hline $\begin{array}{c}\text { Time } \\
\text { contact, } \\
\text { minute }\end{array}$ & $\begin{array}{c}\text { Uranium } \\
\text { content in } \\
\text { the organic } \\
\text { phase, g/L }\end{array}$ & $\begin{array}{c}\text { Uranium } \\
\text { content in } \\
\text { the aqueous } \\
\text { phase, g/L }\end{array}$ & $\begin{array}{c}\text { Uranium } \\
\text { distribution } \\
\text { coefficient }\end{array}$ \\
\hline 1 & 31.0 & 12.0 & 2.58 \\
\hline 3 & 31.0 & 11.95 & 2.59 \\
\hline 5 & 30.5 & 11.75 & 2.59 \\
\hline 15 & 31.5 & 13.18 & 2.4 \\
\hline 20 & 32.0 & 12.70 & 2.52 \\
\hline
\end{tabular}

With a contact time of $20 \ldots 30 \mathrm{~min}$, a degree of uranium re-extraction of $99.9 \%$ can be achieved. Residual carbonate content in the aqueous phase is no more than $150 \mathrm{~g} / \mathrm{L}$. A decrease in excess carbonate content to $100 \mathrm{~g} / \mathrm{L}$ leads to a decrease in the percentage of stripping to 99.7 at.\% $30 \mathrm{~min}$ of contact. With an excess carbonate content in the mother liquor of $200 \mathrm{~g} / \mathrm{L}$ and less than $20 \mathrm{~min}$ of contact time, the percentage of uranium re-extraction decreases to $98 \%$.

The resulting uranium oxide (Table 5) meets the condition in all parameters, except for the phosphorus content. The increased phosphorus content could be explained by the capture of a certain amount of TBP hydrolysis. 
Carbonate mother liquor after uranium stripping contains a significant amount of impurities, the uranium content in it $-0.3 \ldots 1.2 \mathrm{~g} / \mathrm{L}$. The extraction of uranium from the organic phase reaches $97 \ldots 99 \%$. The aqueous phase after five-fold countercurrent extraction contains an increased amount of organic phase, as can be judged from oxidizing ability, which ranges from $237 \ldots 442 \mathrm{mgO}_{2} / \mathrm{L}$. Most of the impurities remain in the aqueous phase after extraction.

Results of studies of uranium re-extraction

Table 4

(uranium content in the original organic phase $30.5 \mathrm{~g} / \mathrm{L}$ )

\begin{tabular}{|c|c|c|c|c|}
\hline Ratio* & $\begin{array}{c}\text { Contact time, } \\
\text { min }\end{array}$ & $\begin{array}{c}\text { Excessive carbonate } \\
\text { content of the mother } \\
\text { liquor, g/L }\end{array}$ & $\begin{array}{c}\text { Uranium content in } \\
\text { the organic phase } \\
\text { after regeneration, g/L }\end{array}$ & $\begin{array}{c}\text { Percentage of } \\
\text { uranium } \\
\text { reextraction, \% }\end{array}$ \\
\hline \multirow{3}{*}{$2: 1$} & 5 & 190 & 0.600 & 98.00 \\
\cline { 2 - 5 } & 10 & 198 & 0.650 & 97.90 \\
\cline { 2 - 5 } & 15 & 192 & 0.250 & 99.20 \\
\cline { 2 - 5 } & 20 & 197 & 0.025 & 99.92 \\
\cline { 2 - 5 } & 30 & 195 & 0.021 & 99.93 \\
\hline \multirow{3}{*}{$1: 1$} & 60 & 196 & 0.028 & 99.91 \\
\cline { 2 - 5 } & \multirow{3}{*}{30} & 105 & 0.086 & 99.72 \\
\cline { 2 - 5 } & & 156 & 0.021 & 99.93 \\
\cline { 2 - 5 } & & 180 & 0.026 & 99.92 \\
\cline { 2 - 5 } & & 195 & 0.028 & 99.91 \\
\hline
\end{tabular}

*organic:mother liquor

Table 5

Chemical analysis of uranium oxide

(re-extraction time $30 \mathrm{~min}$; organic:aqueous $=1: 1 ;$ specific gravity of the organic phase $0.935 \mathrm{~g} / \mathrm{mL}$ )

\begin{tabular}{|c|c|c|c|c|c|c|c|c|c|c|c|c|c|}
\hline \multirow{2}{*}{$\begin{array}{c}\text { Number } \begin{array}{c}\text { Cf } \\
\text { oycles }\end{array} \\
\text { carbonates, } \\
\mathrm{g} / \mathrm{L}\end{array}$} & $\mathrm{U}$ & $\mathrm{Al}$ & $\mathrm{P}$ & $\mathrm{B}$ & $\mathrm{V}$ & $\mathrm{Si}$ & $\mathrm{Cu}$ & $\mathrm{Mn}$ & $\mathrm{Fe}$ & $\mathrm{K}$ & $\mathrm{Na}$ \\
\hline 1 & 220 & 82.12 & 0.002 & 0.73 & $8.8 \cdot 10^{-5}$ & 0.002 & $8.8 \cdot 10^{-3}$ & $3.0 \cdot 10^{-4}$ & $1.7 \cdot 10^{-4}$ & $3.4 \cdot 10^{-3}$ & 0.003 & 0.005 \\
\hline 2 & 197 & 82.55 & 0.003 & 1.80 & $2.2 \cdot 10^{-4}$ & 0.001 & $1.2 \cdot 10^{-2}$ & $2.4 \cdot 10^{-4}$ & $1.8 \cdot 10^{-4}$ & $4.9 \cdot 10^{-3}$ & 0.002 & 0.003 \\
\hline 3 & 205 & 81.14 & 0.002 & 2.20 & $3.2 \cdot 10^{-4}$ & 0.001 & $4.9 \cdot 10^{-3}$ & $8.1 \cdot 10^{-4}$ & $3.5 \cdot 10^{-4}$ & $1.1 \cdot 10^{-2}$ & 0.002 & 0.002 \\
\hline 4 & 197 & 80.17 & 0.009 & 3.00 & $3.7 \cdot 10^{-4}$ & 0.005 & $2.2 \cdot 10^{-3}$ & $2.9 \cdot 10^{-3}$ & $2.7 \cdot 10^{-4}$ & $1.6 \cdot 10^{-2}$ & 0.008 & 0.004 \\
\hline 5 & 197 & 79.97 & 0.008 & 2.10 & $2.0 \cdot 10^{-4}$ & 0.007 & $1.8 \cdot 10^{-3}$ & $4.6 \cdot 10^{-3}$ & $2.0 \cdot 10^{-4}$ & $2.2 \cdot 10^{-2}$ & 0.003 & 0.003 \\
\hline 6 & 187 & 80.74 & 0.007 & 0.64 & $2.7 \cdot 10^{-4}$ & 0.006 & $2.6 \cdot 10^{-3}$ & $1.9 \cdot 10^{-3}$ & $2.6 \cdot 10^{-4}$ & $3.0 \cdot 10^{-2}$ & 0.004 & 0.007 \\
\hline 8 & 204 & 81.54 & 0.027 & 2.70 & $2.9 \cdot 10^{-4}$ & 0.005 & $2.5 \cdot 10^{-3}$ & $1.7 \cdot 10^{-3}$ & $8.1 \cdot 10^{-4}$ & $2.0 \cdot 10^{-2}$ & 0.003 & 0.003 \\
\hline
\end{tabular}

Thus, the increase in the salt composition of the carbonate mother liquor occurs insignificantly over eight cycles. The content of vanadium, phosphorus, and iron in the solution increases slightly. Uranium oxide at eight cycles meets all requirements, except for phosphorus. The uranium content in uranium oxide ranges from 79.97 to $82.55 \%$.

\section{CONCLUSIONS}

1. For the extraction of uranium from nitric acid solutions obtained by dissolving $40 \ldots .50 \%$ chemical concentrates in nitric acid, an extractant consisting of $28 \%$ TBP and $72 \%$ kerosene can be used.

2. From a nitric acid solution containing $46 \mathrm{~g} / \mathrm{L}$ of uranium, after five stages of extraction with a ratio of organic and aqueous phases of $1: 1$, it is possible to obtain a raffinate with uranium content of $\leq 50 \mathrm{mg} / \mathrm{L}$. The same uranium content in the aqueous phase can be obtained from a nitric acid solution containing $105 \mathrm{~g} / \mathrm{L}$ of uranium after six stages of extraction.
3. Coefficient of distribution of uranium by stages of extraction from the nitric acid solutions ranges from 2.5 to 4.0 .

4. The equilibrium content of uranium between the aqueous and organic phases is achieved at a contacting time of 1 min.

5. Re-extraction of uranium from the organic phase with a saturated solution of ammonium carbonate provides $99.9 \%$ efficiency with excess carbonate content in the mother liquor of at least $150 \mathrm{~g} / \mathrm{L}$ and a time of $20 \mathrm{~min}$.

6. The quality of uranium oxide obtained by AUC crystals roasting meets the standard requirements, except for phosphorus.

7. Extraction of uranyl nitrate with a mixture of TBP and kerosene provides a good purification of uranium from impurities of metals, in particular, from molybdenum and vanadium.

8. With the cyclicity of the stripping agent, the uranium content in the uranium oxide ranges from 82.55 
to $79.97 \%$. After eight cycles with a circulating stripping agent, an increase in the content of alkaline impurities in the uranium oxide was still not observed.

9. When uranium is extracted with a mixture of TBP with kerosene from nitric acid solutions obtained by dissolving chemical concentrates in nitric acid, a third phase is formed. This is due to the hydrolysis of TBP and the interaction of mono-butyl-phosphoric acid with uranium, which also leads to an increased content of phosphorus in the uranium oxide.

10. To purify the organic phase from TBP hydrolysis products, an additional dissolution is required, which also reduces the phosphorus content to the standard level.

\section{REFERENCES}

1. A.M. Rosen. Extraction in the nuclear industry. Elements of the extraction technology of spent nuclear fuel from nuclear power plants. Industrial application of natural uranium extraction // Modern problems of chemistry and extraction technology. 1999, v. 1, p. 246264.

2. V.A. Kuznetsov, L.I. Rudin, D.I. Skorovarov. Industrial application of natural uranium extraction // Modern problems of chemistry and extraction technology. 1999, v. 1, p. 265-270.

3. V.I. Nikonov, I.D. Akimova, R.S. Shchipanova, et al. Uranium ore processing method. PatentRF, No. 2434961 // Inventions. Utilitymodels. 2011, N 11, p. 766.

Article received 01.11.2021

\section{ФИЗИКО-ХИМИЧЕСКИЕ ОСНОВЫ ПРОЦЕССА ЭКСТРАКЦИОННОГО АФФИНАЖА ПРИРОДНОГО УРАНА}

\section{А.П. Мухачев, Д.А. Елатонцев, Е.А. Харитонова}

Изложены результаты исследований физико-химических процессов экстракционной азотнокислотной очистки солей урана, полученных методом осаждения уранилтрилкарбоната аммония (УТКА) из рудных растворов выщелачивания урановых и полиметаллических руд с последующим растворением их в азотной кислоте. Показано, что процесс экстракции на смеси трибутилфосфата (ТБФ) в керосине позволяет получить высокочистую закись-окись урана. Для селективного извлечения примесей процесс экстракции урана из азотнокислой среды проводился смесью ТБФ и ди(2-этилгексил) фосфорной кислоты (Д2ЭГФК) в керосине. Первая концентрация урана $40 \ldots 50$ г/л моделировала процесс десорбции урана, вторая $\leq 100$ г/л - процесс растворения закиси-окиси урана. Изучение изотерм экстракции урана позволило определить необходимое число ступеней экстракции для достижения минимального содержания урана в рафинате и максимальной емкости экстрагента, что обеспечило заданные коэффициенты очистки урана от примесей металлов (V, Мо и пр.). Азотнокислотный рафинат после экстракции служил исходным сырьем для производства минерального удобрения - натриевой селитры.

\section{ФІЗИКО-ХІМІЧНІ ОСНОВИ ПРОЦЕСУ ЕКСТРАКЦЙНОГО АФФІНАЖУ ПРИРОДНОГО УРАНУ}

\section{А.П. Мухачов, Д.О. Слатонцев, О.А. Харитонова}

Викладено результати досліджень фізико-хімічних процесів екстракційного азотнокислотного очищення солей урану, отриманих методом осадження уранілтрилкарбонату амонію (УТКА) з рудних розчинів вилуговування уранових та поліметалевих руд з подальшим розчиненням їх в азотній кислоті. Показано, що процес екстракції на суміші трибутилфосфату (ТБФ) у гасі дозволяє отримати високочистий закис-окис урану. Для селективного вилучення домішок процес екстракції урану з азотнокислого середовища проводився сумішшю ТБФ і ді(2-етилгексил) фосфорної кислоти (Д2ЕГФК) у гасі. Перша концентрація урану $40 . . .50$ г/л моделювала процес десорбції урану, друга $\leq 100$ г/л - процес розчинення закису-окису урану. Вивчення ізотерм екстракції урану дозволило визначити необхідну кількість ступенів екстракції для досягнення мінімального вмісту урану в рафінаті та максимальної ємності екстрагента, що забезпечило задані коефіцієнти очищення урану від домішок металів (V, Мо та ін.). Азотнокислотний рафінат після екстракції служив вихідною сировиною для виробництва мінерального добрива - натрієвої селітри. 